\title{
A Discussion on the Improvement of the Construction and Management of Small-scale Farmland Water Conservancy
}

\author{
Ruohan Wang ${ }^{1, a}$ \\ ${ }^{1}$ North China Electric Power University, Beijing, 102206, China
}

\begin{abstract}
Keywords: Small-scale Farmland; Construction of Water Conservancy; Water Management; Countermeasure
\end{abstract}

\begin{abstract}
There are some problems in the construction and management of small-scale farmland water conservancy projects in China, which affects the development of small-scale water conservancy projects to a certain extent. In this case, it is necessary to analyze the construction and management of small-scale water conservancy projects, so as to identify the primary causes of these problems and take reasonable measures to effectively solve and control the problems. Based on the author's research results, this paper first analyzed the main problems and causes in the construction of small-scale farmland water conservancy. Finally, this paper put forward countermeasures to improve the construction and management of small-scale farmland water conservancy.
\end{abstract}

\section{Introduction}

The small-scale farmland water conservancy projects refer to irrigation and drainage projects, small-sized irrigation areas, drought-resistant water projects in irrigation areas, small reservoirs, ponds, reservoirs, water cells, wells and other projects in the field, which aim at providing farmland irrigation and rural drinking water. These small-scale farmland water conservancy projects have a close relation to farmland operations and farmers' daily life. In general, small-scale farmland water conservancy projects play a very important role in fighting agricultural drought, increasing food production, improving the living standard and quality of working people and promoting the further development of agricultural economy in China.

\section{Primary Problems and the Causes in the Construction of Small-scale Farmland Water Conservancy}

They attach importance to the construction and ignore the management of these projects with weak service system and low management and protection level. At present, only a small number of rural small-scale farmland water conservancy facilities are managed by water departments in the city, while the vast majority of water conservancy facilities are managed by the town or village. Most towns only have a water conservancy manager, and some are also in charge of other work. Moreover, some water conservancy managers do not have a high professional ability and their service is low-level. Therefore, they cannot effectively manage and maintain water conservancy facilities. Due to the lack of funds and technical staff, most of towns can only hire old and sick people to manege irrigation and drainage facilities. However, they cannot manage and protect these conservation facilities well.

Facilities are aging and out-of-repair, whose efficiency significantly loses. As the existing rural small-scale farmland water conservancy facilities and farmland projects with a long service time, low standards and the lack of investment are mostly built in the last century, the maintenance and management is poor. Therefore, facilities and equipment are aging and out-of-repair, whose efficiency has significantly lost.

The field irrigation and drainage systems are seriously damaged. In recent years, due to the construction of many projects and over-cultivation in rural areas, some original farmland irrigation and drainage facilities are artificially destroyed. Farmers plow ditches and ponds into cultivated land for planting crops, which blocks water channels. The irrigation facilities lose the capacity of 
irrigation and drainage, which will cause serious risks in combating a drought and drainage in the field.

The capital investment is relatively insufficient and the integration is poor. As the municipal and township governments face financial difficulties and many people go out to work, there is a labor shortage in rural area. The fund raised by farmers is limited. Even if they have labor force, the primary problem cannot be solved. In recent years, the central and provincial finance increases special funds in the construction of small-scale farmland water conservancy and award funds for rural public welfare undertakings. However, these projects are controlled and managed by many departments, so it is difficult to form an overall arrangement of these projects and play the role of all funds in these projects.

\section{Countermeasures to Improve the Construction and Management of Small-scale Farmland Water Conservancy}

To change the concept and raise the awareness of the importance of water conservancy construction. First is to implement administrative leadership responsibility system. The government should take the construction and management of rural small-scale water conservancy facilities as a major livelihood project and implement administrative leadership responsibility system in the flood control and drought relief, the construction of farmland, drinking water safety and security, water resources management, reservoir safety operation and management and river sand mining management. The government should establish a responsibility system of water conservancy work target during the term of administrative leadership. Furthermore, they should take the improvement of farmland water conservancy construction and management as the major content of excellence competition activities in rural area and include it into the performance evaluation of government and the main leading cadres .

Second is to strengthen the department responsibilities. The water department should strengthen the management of water conservancy industry, increase the preparatory work, do a good job in the construction of water conservancy and enhance the management of water conservancy projects; the Development and Reform Commission should make the annual investment plan in accordance with the priorities and make it known to lower levels timely; the financial department should timely schedule funds based on arrangements of budget funds and the progress of the construction of water conservancy projects to ensure the project funds; the Land and Resources Bureau should ensure the land plan indicators of preferential water conservancy projects and guide the project entities to conduct construction land approval procedures in time. Departments of publicity, public security, environmental protection, transportation, forestry, auditing and electricity should bear their respective responsibilities to actively support the construction of water conservancy and take the initiative to do the relevant work.

To strengthen the reform of farmland water conservancy management system. First is to promote the reform of property right system. According to the policies and regulations on the reform of the property right system, the government should deepen the reform of the property right system of small-scale farmland water conservancy facilities, clarify the ownership of the project facilities, define the main protection and management body and improve the management and utilization efficiency of existing facilities. Moreover, they can promote the transfer of property rights with the use of auction, contract, lease, stock cooperation and many other flexible operation models to accelerate the pace of reform of property right system. The township government should integrate the small-scale farmland water conservancy facilities within the administrative area and may authorize the water conservancy department to perform the duties of the investor on the basis of the clean-up, evaluation and confirmation of the asset.

The second is to play the role of farmers' water user associations. In accordance with the principle of voluntary organization, private construction and operation, and common benefit, these associations should support farmers to set up and manage small farmland water conservancy facilities. Furthermore, they should promote new models with farmers participating in water construction and 
management, and improve the relevant management methods and policy measures for the farmers. The government should create a good development environment for water user associations and other water cooperative associations. Water user associations can provide high-quality and convenient full services to farmers.

Third is to establish and improve the township water management and service system, which means to establish and improve the primary water service system with clear functions, rational layout, capable team and satisfying service to comprehensively enhance service capabilities. In addition, the government should establish and improve the township water conservancy stations or small watershed water center stations, approve the personnel and include funds into the city budget, so that there are places, staff, authorized strength, funds and equipment to conduct corresponding work. Moreover, the government should strengthen functions of flood prevention and drought resistance, water management, engineering safety, water conservancy and other public projects, so that the staff can bear the responsibility and the project will be managed by professional people. This will ensure the efficiency of water conservancy projects in a long term.

To strengthen the management of farmland water conservancy construction. First is to establish the program examination and approval system of farmland water conservancy construction and make a scientific and rational plan as the basis for the construction of water conservancy projects. When township and village governments plan to construct small and medium-sized water conservancy projects, such as drilling wells, constructing dam, pumping water, baring the river, building canals, drainage and drop irrigation, they should declare the project location, size and investment plan. After the higher water administrative departments approve, they can implement the project. Civil water conservancy department and the financial sector should exchange information to avoid repetitive project decisions.

Second is to implement project bidding system and project supervision system. The implementation of the project bidding system needs to introduce competition mechanism, standardize the construction management and make a clear project investment. According to the scale of farmland water conservancy project and the size of the beneficial scope, the government should implement management work with different responsibilities and classifications. The city, town and village should implement leadership responsibility system and technical staff responsibility system in the construction of farmland water conservancy projects and make clear responsibility objectives. Moreover, the government should implement publicity system in the project construction to ensure the quality and efficiency of the project, so as to curb corruption in engineering construction.

Third is to establish the acceptance and register system, and implement accountability system. After the completion of the project, the city water department and other relevant departments should conduct a comprehensive acceptance of these projects and all unapproved projects are not allowed to put into service and settle project funds. For those projects that have not been constructed according to the construction procedures, relevant functional departments can make punishment according to the relevant laws and regulations. In particular, relevant departments should severely crack down on projects which are not constructed according to relevant norms and which are low-quality. Within three years after the project acceptance, if the project is damaged due to the construction quality, relevant persons should be investigated for legal responsibility.

To increase investment in the construction of farmland water conservancy. First is to broaden investment channels and strengthen financial support. The government should invest the construction of farmland water conservancy with the use of modern agriculture, sightseeing agriculture, tourism agriculture and modern farming agriculture. Relevant departments should take the government as the leading role and adhere to the the public welfare, fundamental function and strategic role of water conservancy. On one hand, public finance should play its role in protecting the construction of water conservancy; on the other hand, the government should broaden fund channels for the water conservancy construction and lead the whole society to utilize and manage water. Furthermore, the government should encourage social subjects to build water conservancy infrastructure in the form of sole proprietorship, joint venture, cooperation or BOT. In addition, the government should adhere to reform and innovation and establish a more efficient water investment 
system.

The second is to guide farmers to raise money. The government should encourage farmers to raise money with the form of "one project one discussion", so that they can actively participate in constructing small-scale farmland water conservancy facilities. The construction of small-scale farmland water conservancy facilities in the form of "one project one discussion" should follow the principle of "mass voluntary, direct benefit, doing it according to the capability, democratic decisions and reasonable limits". The government can use the policy guidance, financial support, organization and coordination and technical services to encourage and guide farmers to raise funds to participate in the construction of small-scale farmland water conservancy facilities.

To integrate funds, strengthen supervision and establish performance appraisal mechanism. First, in order to improve the use efficiency of funds, we must integrate funds from various channels, highlight the key point and centralize management. At present, the investment funds for small-scale farmland water conservancy construction that come from different channels should be centralized and coordinated, especially the financial capital investment for the construction of farmland water conservancy infrastructure.

Second, according to performance evaluation methods developed by the Ministry of Finance and the province, relevant departments should conduct in-depth performance evaluation and set and further quantify the indicators scientifically. Moreover, they should establish and improve the regulatory mechanism which covers farmland water conservancy construction funds and the construction process to improve the transparency of the allocation and use of farmland water conservancy construction funds. In addition, relevant departments should give full play to the local finance and exploit the advantages to the full of their advantages in supervision, so as to improve the effectiveness of supervision. Furthermore, they should choose key water conservancy construction projects involved in key fields, important areas, large-scale investment and great impact to organize joint supervision and inspection, so as to ensure the use effectiveness of financial funds.

\section{Conclusion}

In the new period, the design of the small-scale farmland water conservancy project is a complicated and systematic job and it is different from the traditional water conservancy engineering design. The engineering design staff must abandon the traditional design concept and rationally take the ecological design measures which reflect the role and value of small-scale farmland water conservancy projects in the new era, so as to save energy, protect the natural ecological environment and promote the development of new socialist countryside. This will improve the construction level of small farmland water conservancy.

\section{References}

[1] Zhu Xianzhong. A Discussion on how to Improve the Construction and Management of Small-scale Farmland Water Conservancy [J]. Rural Finance, 2012,08: 9-10.

[2] Liu Yantao. Several Suggestions on the Construction and Management of Small-scale Farmland Water Conservancy Projects [J]. Water Conservancy, Science and Technology, 2011,05: 49-50.

[3] Deng Zhiping. Suggestions on the Construction and Management of Small-scale Farmland Water Conservancy [J]. South China Agriculture, 2016,12: $242+244$.

[4] Sun Xilong. An Analysis of how to Improve the Construction and Management of Small-scale Farmland Water Conservancy [J]. Science and Technology, 2016,22: 107.

[5] Wang Meiduo. A Study on the Construction and Management of Small-scale Farmland Water Conservancy Facilities -- A Case Study of Construction and Management of Small-scale Water Conservancy Facilities in Faku County [J]. Water Resources Development and Management, 2013,06: 44-45 + 13 .

[6] Zhang Mei. A Study on the Establishment and Improvement of the New Mechanism of Small-scale Farmland Water Conservancy Construction [J]. Henan Science and Technology, 2013,20: 
251.

[7] Huang Jian. A Discussion on the Construction and Management of Small-scale Farmland Water Conservancy Infrastructures [J]. Hunan Water Conservancy and Hydropower, 2015,03: 95-97 +99. 